\title{
KOMUNITAS SURABAYA WOTAGEI: Sebuah Kajian Budaya Populer
}

\author{
Aninditya Ardhana Riswari ${ }^{1^{*}}$ \\ ${ }^{1}$ Graduate Student of Kajian Sastra dan Budaya, Universitas Airlangga, Surabaya, Indonesia
}

\begin{tabular}{|c|}
\hline ARTICLE INFORMATION \\
\hline $\begin{array}{l}\text { Submitted : } 28 \text { February } 2019 \\
\text { Review }: 05 \text { April } 2019 \\
\text { Accepted : } 10 \text { May } 2019\end{array}$ \\
\hline Available online: June 2019 \\
\hline KEYWORDS \\
\hline $\begin{array}{l}\text { Surabaya Wotagei Community, fandom, youth } \\
\text { subculture, AKB48, JKT48 }\end{array}$ \\
\hline CORRESPONDENCE \\
\hline
\end{tabular}

^E-mail: anindityaar@gmail.com

\begin{abstract}
A B S T R A C T
This study analyzes about Surabaya Wotagei Community whose uniqueness is different compared to other communities in Indonesia. Surabaya Wotagei Community emerged not only due to the same preference of the members but also by its uniqueness that is rarely encountered. This study uses qualitative-descriptive method through fandom and youth subculture approaches that emerged in the community. This study shows that Surabaya Wotagei Community is part of the subcultures because they exist as a community that is antimainstream but also stays neutral, as in not trying to fight or oppose something. Surabaya Wotagei Community offers a form of fandom with its own unique characteristics, where its members have other ways to provide support for AKB48 or JKT48 without being obsessive and possessive. On the other hand, as a community, Surabaya Wotagei Community is indeed formed by the popular youth culture which makes this community fluid and is well-known by many circles.
\end{abstract}

mana sebagian orang, atau paling tidak penggemar dan pengikutnya, ingin meniru gaya hidup tersebut. Tak heran jika beberapa di antaranya rela merogoh kocek lebih dalam untuk sesuai, atau paling tidak 'sama', dengan standar hidup sang idola. Mereka juga sanggup untuk membeli barang-barang milik idolanya, walau, mungkin, barang tersebut bukanlah sesuatu yang penting. Kondisi demikian sesuai dengan apa yang disebut Jenkins (1992:12) bahwa penggemar merupakan mereka yang menyukai seseorang bahkan terkesan obsesi dan posesif terhadap idolanya sendiri.

Kehadiran fans pada akhirnya memunculkan fenomena terkait kelompok penggemar yang disebut fans kingdom, atau akrab dikenal dengan fandom. Beberapanya bahkan membuat komunitas guna menunjukkan kehadirannya di tengah-tengah masyarakat. Seperti halnya kemunculan kelompok penggemar Jepang yang keberadaannya kian terasa. Fulamah (2015:2) menyebut bahwa keberadaan kelompok penggemar atas budaya Jepang dapat terlihat dari berbagai situs dan media sosial yang memuat berbagai hal terkait produk budaya populer Jepang. Kehadirannya pun turut berkembang di Indonesia, di mana hal ini menjadi fasilitas bagi penggemar yang sedang menikmati atau mengonsumsi teks budaya yang 
ada guna meluapkan dan menyalurkan kecintaannya terhadap hal tersebut.

$\mathrm{Di}$ sisi lain, Ismail (2017:11) pernah mengemukakan bahwa munculnya proses modernisasi telah banyak membawa perubahan dalam konteks hiburan, seperti halnya yang hadir dalam dunia musik. Di mana pada ranah ini muncul berbagai nama baru yang memiliki tempat di hati para penggemarnya. Salah satunya dapat terlihat dari kehadiran sebuah grup idola kawakan Jepang yang beranggotakan perempuan yakni AKB48. Para penggemar AKB48, yang lebih banyak didominasi anak muda laki-laki, rupanya turut membuat kelompok yang kemudian disebut Otaku atau Wota, yakni sebutan untuk penggemar AKB48.

Kehadiran Otaku atau Wota pada akhirnya menyebar di berbagai wilayah, salah satunya di Indonesia. Apalagi di Indonesia turut muncul JKT48 yakni sebuah grup idola yang dibentuk langsung oleh produser dari AKB48 yakni Akimoto Yasushi. Dengan begitu dapat dikatakan bahwa JKT48 sama halnya seperti AKB48, namun berada di Indonesia. Salim (2015:1) menyampaikan bahwa pengaruh globalisasi dan modernisasi pada dekade 2010an mampu memunculkan sebuah komunitas Wotagei yang hadir di beberapa kota besar di Indonesia seperti halnya Jakarta, Surabaya, Makassar, Solo, dan Yogyakarta. Di mana kehadiran Wota sebagai penggemar disebut tidak jauh dari wujud penggemar pada umumnya, lebih-lebih para Wota yang ada di Indonesia. Seperti yang disebut Hidayati (2015:2) bahwa Wota juga mempunyai merchandise favorit, yang dikoleksi sebagai tanda bahwa sudah seharusnya seorang fans mendukung idolanya dengan cara membeli barang yang dijual oleh sang idola melalui situs resmi yang bersangkutan. Tak hanya itu, kehadiran Wota yang menjamur di berbagai wilayah sering menjadikannya sebagai bagian dari golongan yang cukup obsesi dan posesif terhadap sang idola. Bahkan timbul stigma negatif di kalangan masyarakat terkait kelompok Wota. Hal ini disebabkan, kelompok tersebut didominasi oleh laki-laki yang bahkan rela untuk menunjukkan rasa suka terhadap idolanya dengan cara yang cukup berlebihan.

Berbicara mengenai kondisi tersebut, rasanya banyak masyarakat yang pada akhirnya cukup sepakat dengan anggapan bahwa kelompok ini sama saja dengan kelompok fandom pada umumnya. Namun, anggapan tersebut rupanya justru berbeda dengan yang dihadirkan oleh Komunitas Surabaya Wotagei. Komunitas yang berdomisili di Surabaya ini memiliki gaya tersendiri dalam mendukung sang idola AKB48 atau JKT48. Salah satunya dengan menggunakan light stick dan menarikan tarian yang digunakan untuk memberi dukungan. Komunitas Surabaya Wotagei memiliki cara-cara unik yang hanya dipahami oleh masing-masing anggotanya. Di mana hal tersebut merupakan strategi lain dalam menunjukkan rasa suka bahkan kebanggaan terhadap AKB48 juga JKT48 tanpa harus memiliki barang atau bendabenda seperti yang telah disebutkan sebelumnya, atau tanpa perlu menunjukkan rasa suka yang berlebihan hingga menuju ke sesuatu yang berbau obsesi bahkan posesif. Hal ini tentunya memiliki hubungan dengan fandom dan youth subculture. Di mana terdapat pergeseran makna mengenai fans yang memiliki arti lebih luas, yang muncul dari budaya populer anak muda yang berbeda, yang antimainstream lengkap dengan berbagai macam keunikan di dalamnya.

Dengan demikian, tujuan dari penelitian ini ialah untuk mengetahui bentuk fandom dan youth subculture yang hadir pada Komunitas Surabaya Wotagei. Di sisi lain penelitian ini menjadi penting untuk dilakukan sebab mampu menjabarkan hal-hal atau perbedaan mendasar mengenai sebuah kelompok penggemar yakni Komunitas Surabaya Wotagei, yang memiliki bentuk berbeda dari fandom pada umumnya. Selain itu, tentunya beberapa perbedaan yang hadir pada komunitas tersebut juga dapat memberikan gambaran bahwa budaya anak muda atau yang kerap disebut sebagai budaya populer memiliki perluasan makna seiring dengan perkembangannya di masyarakat.

\section{B. METODE}

enelitian ini merupakan penelitian kualitatif deskriptif. Dengan begitu peneliti mampu memperoleh gambaran yang lebih jelas secara deskriptif terkait objek yang diteliti. Lokasi penelitian bertempat di Balai Pemuda Surabaya yang ada di Jalan Gubernur Suryo No 15 Embong Kaliasin, Genteng, Kota Surabaya. Diketahui bahwa daerah tersebut merupakan tempat anggota Komunitas Surabaya Wotagei berkumpul dan melakukan serangkaian aktivitas seperti halnya menari dan menentukan gerakan yang hendak disajikan. Anggota Komunitas Surabaya Wotagei biasanya berkumpul dalam kurun waktu seminggu sekali, sehingga pertemuan yang dilakukan terjadi secara menerus tiap minggunya.

Informan dalam penelitian ini adalah anggota komunitas yang kemudian dipilih 4 (empat orang). Penentuan informan dilakukan dengan menggunakan teknik purposive sampling sehingga penentuan atas kriteria informan didasarkan pada pengetahuan yang dimiliki terkait objek kajian. Dengan begitu informan mampu memberikan informasi berupa data wawancara, sesuai dengan kebutuhan. Di satu sisi, peneliti tidak berupaya menemui ketua atau pemimpin dari komunitas sebab dalam Komunitas Surabaya Wotagei tidak terdapat ketua atau seseorang yang dijadikan pemimpin, sehingga hal-hal yang berkaitan dengan kelompok masih diselesaikan dengan cara adat. 
Keempat anggota Komunitas Surabaya Wotagei dipilih untuk dijadikan informan karena dianggap mengetahui seluk-beluk munculnya kelompok yang pada akhirnya dijadikan sebagai poros bagi pencinta AKB48 di Surabaya dalam mendukung grup idolanya tersebut. Selain itu, keempatnya diketahui telah menjadi anggota yang cukup lama aktif dalam komunitas. Keempatnya kemudian diwawancarai oleh peneliti melalui wawancara mendalam. Hal ini berkaitan dengan sejak kapan komunitas tersebut terbentuk, seperti apa bentuk dari komunitas, hal-hal apa saja yang mereka lakukan, bagaimana bentuk dan dukungan yang mereka ciptakan guna memberikan dukungan terhadap AKB 48, hingga bagaimana perkembangan komunitas tersebut sampai mampu berada di tengah-tengah masyarakat.

Objek yang dikaji dalam penelitian ini ialah Komunitas Surabaya Wotagei sebagai sebuah kelompok penggemar yang tercipta akibat adanya budaya populer, namun memiliki keunikan tersendiri yang berbeda dari wujud fandom pada umumnya dan dianggotai oleh para anak muda. Oleh sebab itu hal-hal yang berkaitan dengan komunitas baik pembentukannya, fungsi, maupun perkembangannya di masyarakat menjadi sesuatu yang penting dalam penelitian ini.

Kualitatif sendiri menjadi metode penelitian yang dirasa sesuai guna menganalisis sebuah objek, terlebih Komunitas Surabaya Wotagei. Jenis penelitian ini turut dapat dipasangkan dengan model studi kasus, yang mampu mengerucut pada objek penelitian secara lebih khusus dan spesifik. Dengan begitu, data yang digunakan dalam penelitian ini ialah hasil wawancara dari informan sebagai data penting yang telah dikumpulkan. Di sisi lain, dalam kegiatan wawancara yang dilakukan, peneliti dituntut untuk turut serta menjadi bagian dari kegiatan tersebut. Dalam hal ini peneliti menjadi seseorang yang luwes dan tentunya akrab dengan informan guna memperoleh data penelitian yang menyeluruh juga sesuai. Selain wawancara, peneliti turut melengkapi data yang ada dengan melakukan teknik observasi mendalam, sehingga mampu mencocokkan data dari wawancara dengan situasi di lapangan. Selanjutnya, setelah semua data berhasil dikumpulkan maka peneliti melakukan tahap analisis data.

Tahap analisis yang digunakan dalam penelitian ini ialah analisis deskriptif kualitatif yang didasari pada proses pengorganisasian data, memilah-milahnya menjadi satuan yang padu, mencari dan menemukan pola yang sesuai, sampai kemudian mampu menemukan hal-hal penting yang dapat dikaji sebagai hasil akhir. Dengan begitu peneliti berupaya menyampaikan hasil penelitian dalam bentuk analisis data secara deskriptif, yakni mengenai proses hubungan antara data yang didapat di lapangan dengan teori atau pendekatan yang digunakan. Penelitian ini sendiri menggunakan pendekatan fandom dan youth subculture, di mana kehadiran Komunitas Surabaya Wotagei merupakan bentuk atas kelompok penggemar yang muncul dari budaya anak muda, yang kemudian turut mengarah pada budaya populer.

\section{HASIL DAN PEMBAHASAN \\ 1. Komunitas Surabaya Wotagei Sebagai Bagian dari Sub-kultur}

Subkultur merupakan bagian dari kultur atau kebudayaan yang hadir dan membentuk posisinya sendiri dalam budaya yang dominan. Awalan "sub" merujuk pada sesuatu yang kadang dianggap sebagai sebuah ruang bagi "budaya-budaya tandingan", sebab biasanya budaya yang muncul pada subkultur hadir atas bentuk penolakan atau penawaran terhadap hal baru, dari apa yang ada pada budayanya sendiri. Dengan begitu sesuatu yang ada pada subkultur hendaknya membuat sebuah perbedaan yang tidak sama dengan apa yang ada di tatanan budaya pada umumnya. Di sisi lain, subkultur memiliki sifat-sifat yang beririsan, yakni dalam sub kultur terdapat ritual-ritual khas yang memang dilakukan untuk menunjukan eksistensi diri.

Melalui subkultur turut hadir kelompokkelompok yang terbentuk atas sesuatu yang sama, salah satunya tidak menjadi mainstream sehingga mampu menimbulkan sesuatu yang baru dalam segi kebudayaan. Tidak hanya itu, biasanya subkultur juga terbentuk atas usia dan kelas. Dengan begitu dapat diketahui bahwa subkultur hadir untuk memberikan otonomi lain dalam tatanan sosial masyarakat industri yang dirasa kian kaku dan kabur.

Barker (2015:419) menyebut bahwa subkultur merupakan bagian dari sekelompok orang yang diberi label dan sama-sama memiliki nilai dan norma yang khas, yang diyakini berbeda dengan masyarakat mainstream atau masyarakat pada umumnya. Di sisi lain, Barker (2014:342) mengemukakan bahwa titik berat yang hadir dalam subkultur diletakkan pada variasi dari kolektivitas yang lebih luas, yang diposisikan secara sama namun tidak problematis, sebagai sesuatu yang normal, ratarata, dan dominan. Sementara Thornton (Barker, 2014:342) menyampaikan bahwa subkultur dengan kata lain dipandang rendah dan, atau, menikmati satu kesadaran tentang 'ke-lain-an' (otherness) atau perbedaan. Melalui hal tersebut pada akhirnya golongan atau kelompok yang menolak mainstream membuat perkumpulan sebagai bagian dari perwujudan mereka atas kesukaan atau ketertarikan yang sama. Salah satunya ialah Komunitas Surabaya Wotagei. 


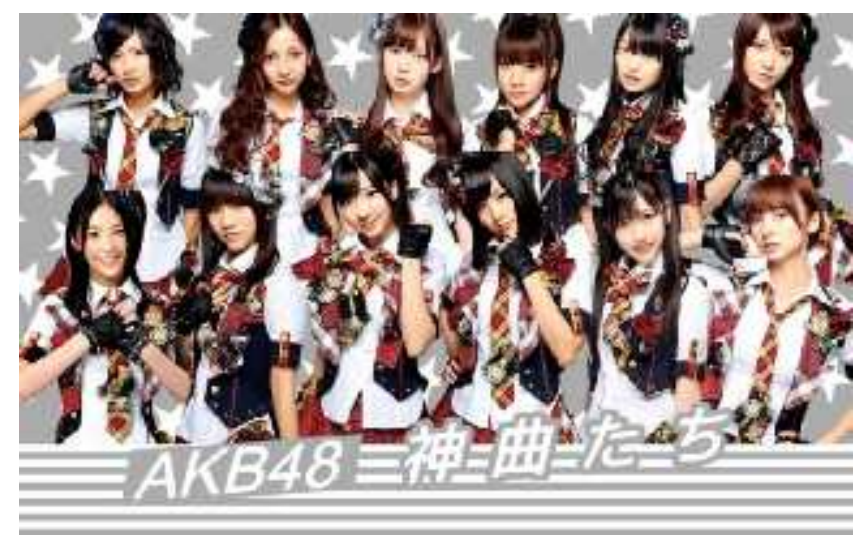

Gambar 1. Group Idola asal Jepang AKB 48

Komunitas Surabaya Wotagei merupakan komunitas bagi mereka yang menyukai dan memiliki kecintaan terhadap grup idola kenamaan Jepang yakni AKB48 (lihat gambar 1). Namun lambat laun komunitas ini juga diperuntukkan untuk mereka para pencinta JKT48, yakni sebuah grup idola asal Indonesia yang diproduseri langsung oleh produser AKB48.

Secara harfiah Wotagei atau Otagei merupakan bentuk sorakan dan gerakan terkait tari khas yang dilakukan oleh penggemar ketika menonton konser sang idola. Idola tersebut pun merupakan idola asal Jepang layaknya AKB48. Dengan begitu dapat diketahui bahwa Wotagei merupakan bentuk dukungan penggemar dalam kegiatan yang dilakukan oleh idolanya. Hal itu yang salah satunya menjadi alasan terkait tersematnya nama Wotagei pada Komunitas Surabaya Wotagei, yakni sebuah kelompok penggemar yang sengaja dibentuk guna memberikan dukungan dan semangat atas idola Jepang baik AKB48 atau JKT48 yang dihadirkan dalam bentuk tarian dan gerakan, terlebih para anggotanya berdomisili di Surabaya.

Di sisi lain, melalui Permana (2014:446) diketahui bahwa AKB48 merupakan grup idola asal Jepang yang anggotanya secara keseluruhan ialah perempuan. AKB48 tidak seperti grup idola pada umumnya. Mereka berbasis teater dan memiliki teater sendiri, tempat untuk melakukan aksi panggung. AKB sendiri berasal dari representasi atas singkatan 'Akihabara', yang merupakan tempat para Otaku (sebutan bagi para anggota Wotagei di Jepang) berkumpul.

Permana (2014:446) menyebut bahwa kehadiran AKB48 atau JKT48 pada akhirnya berubah menjadi racun bagi anak muda di Indonesia, yang mana grup idola tersebut mampu menyasar anak muda dengan jangkauan umur 17 hingga 25 tahun. Namun, tidak sedikit pula orang dewasa berumur 30 tahun ke atas yang turut menjadi bagian dari kelompok penggemar ini. Komunitas Surabaya Wotagei diketahui terbentuk pada tahun 2013 dan masih terus bertahan hingga saat ini. Mulanya pencinta AKB48 di Jepang membentuk gerakan Wotagei yang kemudian membuat para penggemar di negara-negara lain turut menciptakan perkumpulan atau komunitas serupa. Salah satunya seperti yang tersebar di Indonesia, khususnya di Surabaya. Sebab tak dapat dipungkiri bahwa kehadiran AKB48 memang memiliki magnet tersendiri bagi banyak orang. AKB48 memiliki konsep yang berbeda, yang tentunya tidak sama dengan idola atau selebriti kebanyakan, yang pada akhirnya membuat grup idola tersebut memiliki ruang khusus di masyarakat hingga mampu meraup banyak penggemar.

Kehadiran Komunitas Surabaya Wotagei sebagai sebuah kelompok penggemar rupanya juga memiliki keunikan yang kemudian menjadikannya sebagai bagian dari subkultur. Pertama, Komunitas Surabaya Wotagei mampu menghadirkan sesuatu yang baru, yang tentunya tidak mainstream. Sebab komunitas ini bukanlah komunitas penyuka idola pada umumnya yang hanya membentuk perkumpulan untuk sekedar bertemu mengadakan pertemuan atau sekedar berbagi jadwal penampilan dari idola yang mereka sukai. Mereka lebih dari itu. Dalam hal ini mereka justru menghadirkan bentuk dukungan baru melalui terciptanya tarian atau gerakan, yang juga dibarengi dengan pengambilan video dari gerakan tersebut untuk diunggah ke beberapa akun media sosial seperti halnya Youtube. 


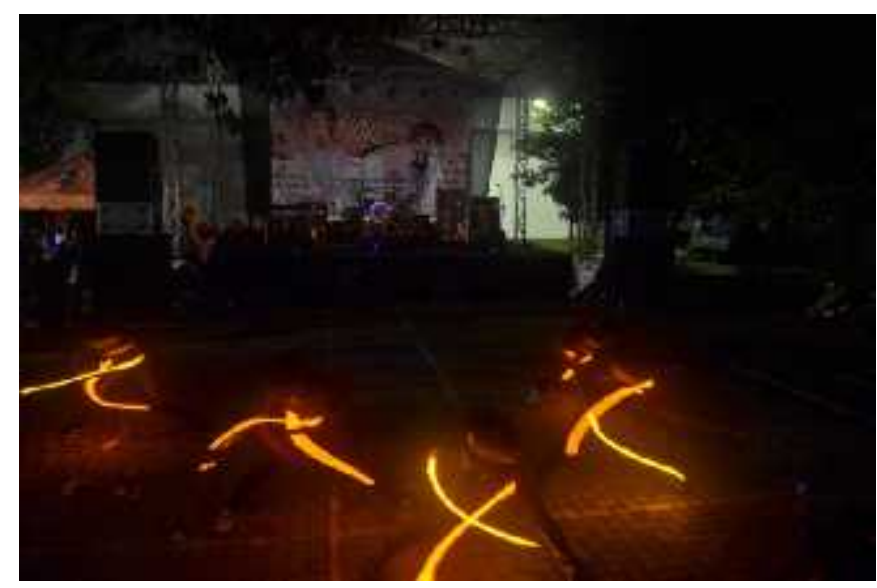

Gambar 2. Komunitas Surabaya Wotagei Saat Tengah Menarikan Tarian (Dokumen Desember 2018)

Mereka pun memiliki cara lain seperti hadirnya light stick yang tidak hanya digunakan untuk berteriak "Oi Oi Oi" saat idola mereka tampil, tetapi juga menjadi salah satu properti yang digunakan untuk menari. Tak heran jika bagian dari komunitas tersebut memiliki anggota yang paham, atau paling tidak, bisa menarikan gerakan yang ada. Walau tak dipungkiri jika tidak semua dari anggota komunitas bisa menari.

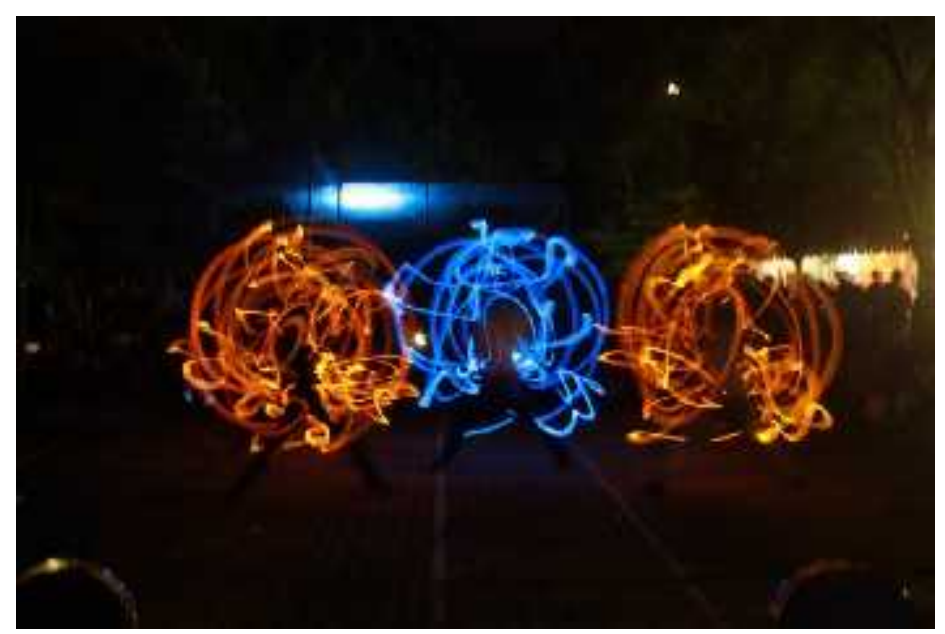

Gambar 3. Komunitas Surabaya Wotagei Saat Tengah Menarikan Dance (Dokumen September 2018)

Kedua, Komunitas Surabaya Wotagei merupakan komunitas milik anak muda yang bisa disebut kekinian dan mereka didominasi oleh laki-laki. Walau tak dapat dipungkiri turut terdapat anggota perempuan dalam komunitas tersebut namun jumlahnya sangat minim. Hadirnya anak muda dalam kelompok penggemar ini justru menjadi sesuatu yang baru, di mana mereka begitu mengetahui dan memahami budaya populer terkait sesuatu yang tengah in di masyarakat. Tak hanya itu, pembentukan mereka sebagai bagian dari subkultur turut membentuk adanya representasi terkait identitas perkumpulan penggemar yang berbeda, yakni memiliki sesuatu yang lain dari perkumpulan pada umumnya. Keanggotaan komunitas yang justru banyak diisi oleh laki-laki pada akhirnya menimbulkan pandangan, juga berupaya menolak stigma yang muncul di masyarakat bahwa penggemar sebuah atau sekelompok idola tidak hanya identik dengan perempuan, tetapi juga bisa laki-laki. Terlebih di dalamnya mereka juga berupaya untuk menarikan tarian dan teriakan untuk memberikan semangat terhadap sang idola.

\section{Komunitas Surabaya Wotagei: Fandom dan Youth Subculture \\ a) Komunitas Surabaya Wotagei Sebagai Bagian dari Fandom}

Munculnya Komunitas Surabaya Wotagei sebagai bagian dari subkultur turut memiliki hubungan erat dengan fandom. Seperti halnya yang disampaikan Tartila (2017:3) bahwa fan dalam fandom merupakan bagian subculture fans yang menawarkan ruang untuk komunitas yang memungkinkan orang-orang dengan latar belakang dan pengalaman yang beragam, yang kemudian membentuk mereka atas ikatan 
dengan minat yang sama. Fandom mampu menciptakan ruang di mana orang-orang yang hadir di dalamnya mampu mengekspresikan diri pada tatanan yang sebenarnya. Hal itu yang turut muncul dalam Komunitas Surabaya Wotagei yang terbentuk dari orang-orang dengan latar belakang yang beragam namun memiliki ikatan atas kesukaan yang sama terhadap seseorang atau sekelompok idola. Di sisi lain, hal tersebut juga mengarah pada budaya anak muda yang memang lebih menikmati budaya populer, lebih-lebih yang sedang berkembang dan muncul di tengah masyarakat.

Jenkins (1992:12) menyebut bahwa fandom mulanya muncul dari kata 'fan' yang merupakan singkatan dari kata 'fanatik', yang berakar dari kata latin fanaticus. Mulanya, 'fan' dikenal sebagai sesuatu yang negatif sebab identik dengan seorang pelayan kuil dan sebuah pemujaan. Tak heran jika sebelum memasuki era kontemporer, kata fans merupakan sebutan bagi mereka yang tergila-gila dengan pemujaan agama atau iblis. Akan tetapi lambat laun hal tersebut mengalami pergeseran, di mana fans saat ini justru memiliki arti sebagai orang yang menyukai, bahkan mempunyai obsesi terhadap seseorang atau idola.

Hadirnya Komunitas Surabaya Wotagei jelasnya memiliki kaitan erat dengan fandom, di mana AKB48 menjadikan mereka berkumpul hingga memiliki kedudukan juga identitas diri yang sama sampai kemudian mampu membentuk sebuah jaringan yakni komunitas itu sendiri. Namun, rupanya Komunitas Surabaya Wotagei turut memiliki sisi lain yang berbeda yang tidak selalu sepadan dengan ciri penggemar pada umumnya. Bahkan tidak pula sama dengan beberapa komunitas Wotagei lain.

Semisal bagi Komunitas Surabaya Wotagei mencintai idola tidak hanya dibuktikan dengan memiliki barang atau benda yang dijual, atau bahkan menjadi obsesi yang berlebihan. Sebab mempunyai barang layaknya merchandise, photopack, atas AKB48 atau JKT48 hanyalah menjadi opsi lain yang bisa dilakukan sehingga bukanlah sebuah kewajiban. Mereka justru berpikir bahwa dukungan dan semangat dapat pula dilakukan dengan menarikan tarian dari AKB48 atau JKT48 yang turut dimodifikasi oleh para anggota komunitas, yang kemudian diunggah di beberapa akun media sosial seperti halnya Youtube.

Seperti yang disampaikan sebelumnya, jika tarian yang ditarikan oleh para penggemar AKB48 atau JKT48 hanya diwujudkan dalam bentuk gerakan serentak guna menyemangati para idola yang tengah tampil, maka lambat laun tarian atau gerakan yang ditunjukkan tidak hanya mengarah pada saat sang idola manggung. Gerakan tersebut dapat pula ditampilkan ketika mereka tengah berkumpul antar sesama anggota komunitas, yang kemudian mereka unggah di akun media sosial. Tak hanya itu, bahkan Komunitas Surabaya Wotagei turut beberapa kali diberi kesempatan untuk menarikan gerakan yang mereka modifikasi di ruang-ruang publik seperti halnya Japanese World di Surabaya. Dengan begitu, kondisi demikian agaknya menjadi bentuk dukungan nyata yang tentunya membuat idola yang bersangkutan yakni AKB48 atau JKT48 mengetahui bahwa penggemarnya turut mencintai karya yang dihasilkan. Terlebih hal ini justru menunjukkan bahwa Wota turut memiliki eksistensi yang cukup besar di kalangan masyarakat. Kondisi demikian yang pada akhirnya disebut sebagai hasil dari produktivitas fans terhadap idolanya. Di mana fans menunjukkan sesuatu atau, bahkan, menghadirkan sesuatu yang berbeda dan baru guna mendukung idola. Produktivitas itu sendiri dapat terlihat dari tarian modifikasi juga keloyalan tinggi yang muncul dari anggota komunitas untuk sang idola yakni AKB48 atau JKT48. Dengan begitu tak heran jika Komunitas Surabaya Wotagei memiliki ciri atau kebiasaan yang bahkan merujuk pada identitas pribadi sebagai sebuah kelompok.

Barker (2014:260) menyebut bahwa dalam wacana budaya tentang "diri" dalam tradisi pemikiran Barat mengasumsikan bahwa kita mempunyai jati diri yang sejati, yang biasa dikenali dan diekspresikan lewat beberapa bentuk representasi. Dengan demikian, identitas diri dapat bersifat esensial, universal, dan abadi. Akan tetapi munculnya identitas diri juga tidak dapat terlepas dari pengaruh sosial budaya. Hal ini yang rupanya turut muncul dan berkembang dalam Komunitas Surabaya Wotagei, yakni diketahui bahwa identitas yang mereka bentuk tentunya tidak jauh dari proses sosial budaya yang dilalui dan dialami oleh masing-masing anggotanya.

Identitas lain yang menjadi ciri khas mereka ialah light stick yang memang kerap kali muncul ketika melakukan sebuah tarian. Light stick telah menjadi 'nyawa' bagi komunitas ini. Terlebih, tarian yang dihadirkan juga merupakan bagian dari identitas. Apalagi tarian yang disajikan masing-masing gerakannya memiliki makna yang mengarah pada kehadiran Dewa. Hal ini yang tentunya memunculkan sebuah identitas baru, seperti golongan atau kelompok mana lagi yang berupaya memberikan dukungan kepada idolanya dengan bentuk tarian, yang kemudian juga ditarikan oleh mereka para laki-laki?

Kondisi demikian yang pada akhirnya membentuk dan memunculkan anggapan menarik yang mungkin bagi sebagian orang tidak disadari. Sebab laki-laki atau mereka yang tergabung dalam Komunitas Surabaya Wotagei rupanya juga cukup sering mendapat cemooh atau anggapan negatif dari lingkungan sekitar, karena dianggap fanatik dan cukup aneh. Situasi tersebut juga dibarengi dengan pernyataan 
beberapa orang yang merasa bahwa 'tidak sepantasnya laki-laki menjadi bagian dari penyuka grup idola apalagi grup ini merupakan gabungan dari perempuan-perempuan berbakat. Terlebih laki-laki menjadi mau dan tidak malu untuk menunjukkan kesukaan mereka dengan berteriak Oi Oi Oi dan menari menggunakan lighstick'. Namun, menanggapi hal tersebut salah seorang anggota Komunitas Surabaya Wotagei bernama Indra menuturkan bahwa ia tidak mau membalas komentar yang ada. Sebab baginya, kesukaan terhadap AKB48 ataupun JKT48 tidaklah mengganggu privacy di kalangan banyak orang juga tidak menimbulkan keresahan di masyarakat. Di sisi lain, ia merasa bahwa komunitas yang ia naungi bukanlah kelompok yang cukup fanatik hingga menimbulkan rasa obsesi dan posesif yang berlebihan terhadap idola yang mereka cintai.

Hal menarik lain rupanya turut terlihat dari pasang surut keanggotaan dalam Komunitas Surabaya Wotagei. Komunitas ini tidak mengikat anggotanya untuk menjadi seseorang yang sesuai dengan keinginan dari komunitas, sehingga tidak ada sesuatu yang wajib dilakukan oleh masing-masing anggota. Di sisi lain, masukkeluarnya anggota dalam komunitas bukan disebabkan karena menurunnya rasa cinta atau keloyalan terhadap idola yang ada, juga bukan karena merasa tidak satu visi dengan komunitas, melainkan hal ini terjadi sebab adanya kesibukan di luar kelompok yang tidak bisa ditinggalkan, yang pada akhirnya menyebabkan anggota tersebut memilih untuk keluar. Namun jalinan hubungan antar anggota, baik yang sudah keluar atau yang masih bertahan, masih terus berjalan baik hingga saat ini.

Sementara itu, Permana (2014:448) pernah menyebut bahwa terminologi dalam fandom AKB48 atau JKT48 sebenarnya tidak memiliki tingkatan atau strata yang resmi untuk bergabung di dalamnya. Akan tetapi, ternyata terdapat strata atau tingkatan yang terbentuk melalui seberapa seringnya seorang penggemar datang ke teater, intensitas bertemu dengan member, dan tingkat kekayaan fans. Tingkat kekayaan yang dimaksud di sini bukan hanya tingkat kepemilikian barang koleksi atau swag yang oleh sebagian kalangan fans dijadikan sebagai tingkat "seberapa loyal-kah kamu terhadap oshi-mu" atau "seberapa cintakah kamu terhadap AKB48 atau JKT48". Namun, salah seorang informan lain yang ditemui oleh peneliti menyebut bahwa dalam Komunitas Surabaya Wotagei terminologi terkait hal itu justru tidak ditemui. Bahkan, informan mengaku belum pernah satu kali pun bertemu dengan member AKB48 atau JKT48, tetapi ia tetap merasa senang dan menyukai AKB48 serta merasa cukup aktif berada di komunitas yang ia naungi. Artinya, bentuk strata atau tingkatan mengenai proses-proses apa yang telah dilalui guna mencintai sang idola tidak mempengaruhi seseorang untuk menentukan dan menunjukkan dirinya dalam komunitas ini. Sebab hal demikian justru juga dapat terwujud dengan tetap melakukan kegiatan aktif dan produktif bagi perkembangan komunitas. Tidak hanya itu, Komunitas Surabaya Wotagei turut membuka celah bagi siapa saja yang hendak bergabung menjadi bagian dari kelompok penggemar ini sehingga hal-hal terkait latar belakang yang berkaitan dengan kekayaan atau barang-barang layaknya merchandise apa yang mereka punya, bukanlah hal utama yang diwajibkan.

Dengan begitu pada akhirnya dapat pula diketahui bahwa strata yang ada pada fandom terkait AKB48 atau JKT48 tidak sepenuhnya hadir pada fandom atas Wota di lokasi atau wilayah lain. Seperti halnya yang ada di Komunitas Surabaya Wotagei. Hal ini jelas menunjukkan adanya kecenderungan lain berkaitan dengan bentuk fandom yang dimiliki oleh Komunitas Surabaya Wotagei, yang tentunya berbeda dari komunitas Wota lainnya.

Tak hanya itu, Salim (2015:2) mengemukakan bahwa atas dasar kegemaran yang sama, maka mereka para anggota atas kelompok penggemar yang kemudian membentuk komunitas, hendaknya turut memiliki rencana terkait program ke depan yang akan dilakukan guna menunjukkan kecintaan terhadap sang idola. Dengan begitu dibutuhkan adanya koordinasi yang baik dalam sebuah komunitas yang tentunya dipimpin oleh seseorang dengan gaya kepemimpinan yang sesuai bagi kalangan mereka. Namun rupanya hal tersebut justru berbeda dari Komunitas Surabaya Wotagei, di mana kemunculannya sebagai sebuah perkumpulan yang dinamai komunitas, bahkan, masih bersifat tradisional, sehingga segala sesuatu yang dilakukan akan diselesaikan sesuai dengan kesepakatan adat. Mereka sendiri mengaku tidak memiliki ketua atau leader dalam komunitas ini. Hal tersebut tentunya memiliki hubungan dengan tingkatan yang sebelumnya sempat disampaikan, bahwa dalam Komunitas Surabaya Wotagei justru tidak ada kedudukan terkait strata. Dengan begitu, masing-masing anggotanya justru mempunyai rasa memiliki yang sama terhadap komunitas yang mereka naungi.

Oleh sebab itu kemudian dapat disimpulkan bahwa keberadaan atas kelompok penggemar yang merujuk pada fandom, pada akhirnya mengalami pergeseran seiring berjalannya waktu. Hal-hal yang berkaitan dengan kefanatikan atau obsesi terhadap idola, bahkan tidak ditemui pada Komunitas Surabaya Wotagei. Padahal komunitas ini berada di tengah kota besar kedua di Indonesia yakni Surabaya. Kondisi tersebut paling tidak membuat anggota di dalamnya berupaya berlomba untuk meraih kedudukan yang lebih, seperti halnya melakukan berbagai usaha untuk dapat menemui sang idola. Akan tetapi, pada kenyataannya obsesi 
atau keinginan berlebih tersebut tidak ditemui pada kelompok ini. Mereka, yang berasal dari berbagai macam latar belakang, justru dapat bersatu guna menghadirkan wujud lain atas kelompok penggemar yang dirasa jauh lebih positif, yakni salah satunya dengan menghasilkan karya sebagai bentuk ekspresi diri mengenai kecintaan terhadap sang idola yaitu JKT48 dan AKB48.

\section{b) Komunitas Surabaya Wotagei dan Youth Subculture}

Komunitas Surabaya Wotagei hendaknya turut dapat dipahami sebagai bagian dari youth subculture, yakni budaya anak muda. Meski seperti yang telah disebutkan sebelumnya bahwa komunitas Wota rupanya juga menyasar usia 30 tahun ke atas, namun yang menjadi bagian utama dan aktif dalam komunitas tersebut ialah anak-anak muda. Dalam Komunitas Surabaya Wotagei sendiri keberadaan dan terbentuknya kelompok ini justru berangkat dari ide anak muda yang kemudian didominasi oleh hadirnya anggota-anggota lain yang berkisar di antara usia 18 hingga 24 tahun.

Mulanya budaya anak muda yang ada pada komunitas Wota berasal dari munculnya AKB48 dan JKT48 yang hadir sebagai sesuatu yang memang tengah popular di masyarakat, yang kemudian membuat para pencintanya berkumpul hingga membentuk sebuah jaringan komunitas. Barker (2014:305) menyampaikan bahwa budaya anak muda tidak hanya melulu mengarah pada mereka yang melakukan aksi kejahatan juga kenakalan, melainkan turut dapat ditampilkan sebagai konsumen fashion, gaya, dan aktivitas mengisi waktu luang. Dengan demikian, munculnya Komunitas Surabaya Wotagei lebih-lebih merupakan bagian dari anak muda yang memang muncul akibat adanya teknologi komunikasi, yang dewasa ini mampu menciptakan komoditas, makna, dan identifikasi bagi budaya kaum muda itu sendiri tanpa harus menyasar pada sesuatu yang bersifat negatif.

Oleh sebab itu, tak heran jika AKB48 atau JKT48 yang menjadi idola Komunitas Surabaya Wotagei, lengkap dengan segala macam aktivitasnya, mampu menjadi bagian dari budaya bersama, yang turut dapat dinikmati secara bersamaan. Di sisi lain Willis (Barker, 2016:361) menyebut bahwa budaya bersama yang dinaungi oleh anak muda merupakan bentuk dalam memiliki satu relasi yang aktif, kreatif, dan produktif secara simbolis dengan komoditas yang membentuk budaya anak muda itu sendiri. Makna tersebut dihasilkan melalui proses pemakaian secara aktual sehingga tidak melekat sewaktu-waktu. Hal ini jelas terlihat dari Komunitas Surabaya Wotagei yang mampu menunjukkan relasi aktif, bukan hanya pada keterkaitan antar orang di dalamnya melainkan juga dengan komunitas Wotagei lainnya baik yang ada di Surabaya atau kota-kota lain.

Lebih lagi, mereka juga memiliki peran kreatif dan produktif untuk menjadikan komunitas yang mereka miliki, bukan hanya sekedar komunitas kumpul-kumpul, melainkan juga menghasilkan sesuatu. Kondisi demikian dapat terlihat dari kegiatan mereka saat tengah berkumpul di Balai Pemuda Surabaya, di mana dalam kesempatan yang ada mereka bukan hanya sekedar menanyakan kabar, membicarakan member kesukaan masing-masing, atau agenda terdekat dari AKB48 juga JKT48, melainkan mereka turut membicarakan ide-ide terbaru mengenai tarian apa yang hendak ditarikan pada pertemuan selanjutnya atau pada pengambilan video yang akan datang. Bahkan tak jarang mereka turut mendiskusikan kegiatan atau agenda yang hendak digarap secara kolektif guna memberikan perkembangan terhadap kehadiran komunitas itu sendiri. Hal ini yang pada akhirnya membuat Komunitas Surabaya Wotagei menjadi sebuah perkumpulan bagi anak-anak muda yang dirasa aktif, kreatif, juga produktif. Sebab mereka mampu mengolah hingga menghasilkan sesuatu yang baru, yang, paling tidak, bermanfaat bagi komunitas itu sendiri.

Sementara itu turut diketahui bahwa komunitas Wotagei secara umum telah tersebar hingga ke beberapa negara lain. Wotagei bahkan dikenal di Amerika dan China. Tak hanya itu, semakin hari penampilan yang mereka sajikan tidak hanya menggunakan lagu-lagu AKB48 atau lagu-lagu Jepang melainkan juga dengan menggunakan lagu pop asal Inggris atau Korea. Di sisi lain komunitas serupa, yang hampir mirip dengan Wotagei, turut hadir di Korea. Bedanya, jika di Korea kelompok yang muncul sengaja diperuntukkan untuk mereka para kelompok idola di negeri ginseng tersebut. Kondisi demikian pada akhirnya memunculkan sesuatu yang menarik, sebab rupanya apa yang dilakukan dan dihadirkan oleh para kelompok Wota mampu menjadi kiblat juga berhasil membentuk sesuatu yang dianggap populer. Dengan demikian hal ini berpengaruh terhadap munculnya budaya populer itu sendiri.

Salim (2015:18) menyebut bahwa Wotagei, lebih-lebih Komunitas Surabaya Wotagei, ialah kelompok penggemar yang merupakan bagian dari budaya populer di kalangan remaja perkotaan yang kehadirannya tidak terlepas dari media massa. Di mana media massa memberikan dampak signifikan terhadap industri yang diciptakan, yakni yang berkaitan dengan Wotagei dan hal-hal terkait ke-Jepang-Jepangan itu sendiri. Seperti yang disampaikan Barker (2014:210) bahwa budaya populer selalu tak lepas dari barang atau jasa yang diproduksi secara komersial. Namun penikmatnya berhak untuk membentuk sendiri makna yang mereka mau dari teks-teks budaya yang muncul. Dengan 
kata lain, dapat disebut bahwa masing-masing penikmat turut membawa serta kompetensi kultural serta sumber daya diskursif yang mereka miliki dalam mengonsumsi komoditas yang ada.

Berdasarkan uraian tersebut dapat diketahui bahwa Komunitas Surabaya Wotagei dan kaitannya dengan youth subculture mampu membentuk sebuah jaringan unik, yang mana mereka hadir atas buah konsumsi dari keberadaan media massa. Kehadirannya yang berada di tengah masyarakat, khususnya di kota besar, membuat komunitas ini mudah dikenali. Apalagi mereka menjadi salah satu kelompok penggemar di kalangan anak muda yang berhasil memperkenalkan sesuatu yang berbeda, yang bukan hanya berkumpul atas dasar kesukaan hingga menghadirkan bentuk eksklusif, melainkan mereka mampu melakukan berbagai agenda produktif dalam rangka mengembangkan komunitas yang dinaungi. Di sisi lain, Komunitas Surabaya Wotagei mampu menjadi contoh atas keberadaan sebuah kelompok yang menawarkan sesuatu yang tidak sama dengan komunitas pada umumnya, yakni salah satunya mereka berhasil menghadirkan kebaruan bahwa penggemar atas idola tidak lah melulu perempuan. Bahkan laki-laki pun mampu memunculkan sesuatu yang dirasa positif hingga dikenal aktif di banyak kalangan tanpa harus dikatakan buruk. Dengan begitu dapat pula disimpulkan bahwa keberadaan Komunitas Surabaya Wotagei rupanya memiliki keterkaitan mendalam atas fandom dan youth subculture, yang dibarengi dengan hubungannya terhadap hal-hal lain yakni budaya populer, budaya masa, dan pembentukan atas identitas diri.

\section{PENUTUP}

$\mathrm{M}$ elalui penelitian yang telah dilakukan dapat diketahui bahwa sejatinya setiap penggemar yang tergabung dalam fandom hendaknya memiliki cara pun strategi yang dilakukan guna mendukung idolanya. Namun rupanya turut terdapat caracara berbeda yang bahkan mengarah pada sesuatu yang unik, baik dalam bentuk perlakuan maupun perspektif atas sesuatu terkait sang idola. Hal ini yang juga hadir pada Komunitas Surabaya Wotagei, di mana komunitas ini memiliki ciri khas yang berbeda yang justru membuat mereka menjadi sesuatu yang antimainstream.

Pertama, Komunitas Surabaya Wotagei merupakan bagian dari kelompok penggemar yang bahkan bisa disebut bagian dari subkultur. Sebab mereka menghadirkan sesuatu yang baru, yang berbeda dari kelompok penggemar selebriti pada umumnya. Kesukaan terhadap AKB48 juga JKT48 mereka wujudkan dalam bentuk tarian dan gerakan serta teriakan yang memang ditampilkan dalam beberapa kesempatan, bukan hanya saat AKB48 atau
JKT48 tampil melainkan juga mewujudkannya dalam video-video dance yang diunggah di akun Youtube. Hal ini jelas berbanding terbalik dengan hadirnya komunitas penggemar selebriti lainnya yang justru berkumpul guna membicarakan agenda atau hal-hal terkait idola yang mereka sukai. Dengan begitu dapat disimpulkan bahwa Komunitas Surabaya Wotagei turut membentuk sesuatu yang baru di tengah-tengah masyarakat. Oleh sebab itu bisa disebut bahwa Komunitas Surabaya Wotagei muncul atas sebuah representasi baru mengenai jaringan komunitas, yang mana kelompok ini bahkan berhasil bertahan dan berkembang, bahkan memiliki tempat di ruang publik.

Kedua, Komunitas Surabaya Wotagei menawarkan sesuatu yang berbeda, yang bahkan tidak sama dengan kelompok Wota lain. Jika beberapa kelompok Wota justru menunjukkan rasa obsesif, posesif, bahkan diehard yang berlebihan terhadap AKB48 atau JKT48, salah satunya dengan cara membeli dan mengoleksi merchandise dari sang idola atau mati-matian berupaya meluangkan waktu guna dapat bertemu dengan member yang diidolakan, namun hal ini tidak berlaku bagi Komunitas Surabaya Wotagei. Surabaya Wotagei justru menjadi komunitas dengan basis kekeluargaan yang cukup tinggi, di mana tidak terdapat peraturan dan strata yang mengikat sehingga membuat masing-masing anggota mempunyai rasa kepemilikan yang sama terhadap idola mereka tanpa ada maksud saling mengungguli. Dengan begitu diketahui bahwa Komunitas Surabaya Wotagei memiliki ikatan yang dirasa cukup longgar, sehingga tidak ada sesuatu yang bersifat ketat, yang hadir seperti pada komunitas Wota kebanyakan. Oleh karenanya kemudian dapat pula disimpulkan bahwa kehadiran komunitas ini justru mampu menggeser anggapan juga pandangan terhadap sebuah kelompok penggemar, lebih-lebih pencinta AKB48 dan JKT48, yang rupanya tidak hanya melulu dirasa fanatik dan aneh melainkan Komunitas Surabaya Wotagei justru membentuk jaringan yang mampu dekat dan dikenal di lingkup masyarakat lingkungannya.

Ketiga, Komunitas Surabaya Wotagei ialah komunitas yang hadir dan muncul di tengahtengah masyarakat, khususnya anak muda. Tak heran jika kemudian komunitas ini merupakan bagian dari youth subculture, sebab dibentuk dan dikembangkan sendiri oleh anak muda dengan sesuatu yang tengah populer di masyarakat yang pada akhirnya membuat komunitas ini mudah dikenali. Tak hanya itu, Komunitas Surabaya Wotagei merupakan perwujudan atas fandom juga sub budaya anak muda yang dirasa lebih kekinian, yang kerap disebut sebagai budaya populer sehingga mampu membuat banyak orang, paling tidak, ingin mengenali dan mengetahui kelompok tersebut. 
Di sisi lain hadirnya anggota komunitas yang mayoritas beranggotakan laki-laki ini hendaknya menjadi sesuatu yang menarik, yang membuat komunitas Wota memiliki sesuatu yang berbeda dari para kumpulan fans kebanyakan. Hal ini pula yang memicu pertanyaan, apakah ini termasuk bagian dari gerakan kaum lelaki (men's movement)? Di mana seperti yang disebut Barker (2014:170) bahwa gerakan ini muncul untuk mengimbangi, mengoreksi, atau bahkan memperbaiki gerakan perempuan. Namun yang tak boleh dilupakan ialah, dalam komunitas ini turut termuat nilai-nilai sosial, di mana masingmasing anggota di dalamnya mengaku menjalin kekerabatan yang baik tanpa memiliki upaya untuk saling menjatuhkan. Kondisi ini yang memunculkan suasana budaya yang menyenangkan, yang tentunya hadir dari gerakan anak muda.

\section{E. UCAPAN TERIMA KASIH}

$\mathrm{P}$ eneliti berterima kasih kepada Magister Kajian Sastra dan Budaya Universitas Airlangga atas kepercayaan yang diberikan untuk menyelesaikan artikel ini.

\section{DAFTAR PUSTAKA}

Barker, Chris. (2014). Kamus Kajian Budaya. Sleman: Kanisius.

Barker, Chris. (2015). Cultural Studies: Teori dan Praktik. Bantul: Kreasi Wacana.

Bourdaa, M., and Javier Lozano. (2016). Contemporary Participative TV Audiences: Identity, Autorship and Advertising Practices Between Fandom. Journal Participations Volume 13. Page 2-13.

Choi, Yun-Jung. (2011). The Globalization of K-Pop: Is K-Pop Losing its Korean-ness?. Journal Situations 5. Page 61-67.

Fauziah, R., dan Diah Kusumawati. (2013). Fandom K-Pop Idol dan Media Sosial. Jurnal. Universitas Sebelas Maret Surakarta.

Fitri, Annisaa. (2015). Fandom dan Media (Analisis Isi Kualitatif Pesan Tweet dalam Fandom Slash pairing Wonkyu di Twitter pada Kalangan Shipper di Jakarta). Jurnal. Universitas Sebelas Maret Surakarta.

Fulamah, Furi Nur. (2015). Konstruksi Identitas Kelompok Penggemar (Fandom) Fanfiction di Kalangan Remaja Urban. Jurnal Universitas Airlangga.

Harrington, C. L., \& Bielby, D. (2010). A life Course Perspective on Fandom. Journal of Cultural Studies.

Hidayati, Widya Nur. (2015). Pengalaman Komunikasi JKT48 dalam Fandom JKT48. Skripsi. Universitas Diponegoro Semarang.

Ismail, Rokiah. (2017). Musik Rock Alternatif dalam Kalangan Remaja: Isu Sub-budaya Remaja dan Pembangunan Insan dalam Era Globalisasi. Jurnal Antropologi dan Isu-isu Sosial Budaya (Jantro). Halaman 11-25.

Jenkins, Henry. (1992). Textual Poachers: Television Fans \& Participatory Culture. New York: Routledge.

Jenkins, Henry. et, al. (2009). Confronting The Challengess of Participatory Culture: Media Education for the 21st Century. Massachusetts: MIT Press.

Otmazgien, N., and Irina Lyan. (2013). Hallyu Across The Desert: K-Pop Fandom in Israel and Palestine. Journal. Cross-Currents: East Asian History and Culture Review E-Journal No.9. Page 68-89.

Permana, Andika. (2014). Studi Fandom JKT48 Sebagai Pop Culture. Jurnal Common Line Departemen Komunikasi Volume 3. Page 442-453.

Pramudyaningsih, Novi Rahayu. (2013). Pengaruh Penggunaan Selebriti dalam Iklan Terhadap Minat Beli Konsumen Pelembab Muka Pond's di Kota Semarang. Jurnal. Fakultas Ekonomi dan Bisnis Universitas Dian Nuswantoro Semarang.

Ruslan, Rosady. (2010). Manajemen Public Relations \& Media Komunikasi. Jakarta: RajaGrafindo Persada.

Salim, Rachmat Lukman Hakim. (2015). Gaya Hidup Komunitas Wotagei di Surabaya. Skripsi. Universitas Gadjah Mada Yogyakarta.

Sari, Ratna Permata. (2012). Fandom dan Konsumsi Media: Studi Etnografi Kelompok Penggemar Super Junior, ELF Jogja. Jurnal Komunikasi Volume 6. Halaman 79-90. 
Aninditya Ardhana Riswari/JURnal AntropologI: ISU-ISU SOSIAL BUDAYA - Vol. 21 No. 01 (JUNE 2019)

Tartila, Pintani Linta. (2017). Fanatisme Fans KPop dalam Blog NetizenBuzz. Jurnal. Universitas Airlangga.

Webb, Adam. (2009). Music Experience and Behaviour in Young People Spring 2008. Journal. British Music Rights University of Hertfordshire. 